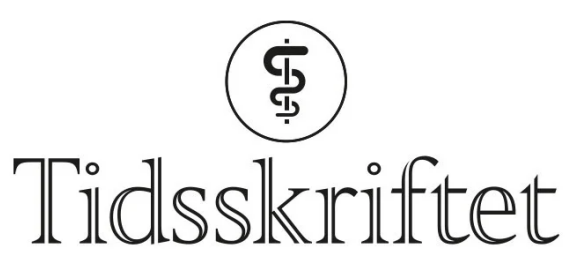

DEN NORSKE LEGEFORENING

\title{
Perinatal død og ny teknologi
}

\author{
KOMMENTAR
}

\section{HILDE ENGJOM}

hilde.engjom@uib.no

Hilde Engjom er overlege og postdoc ved Folkehelseinstituttet og Haukeland universitetssykehus. Forfatteren har ikke oppgitt noen interessekonflikter.

Takk til forfatterne for et viktig og spennende arbeid (1). Jeg savner informasjon om håndtering av alvorlige medfødte misdannelser i datamaterialet. Er disse svangerskapene ekskludert fra analysene? Bedre undersøkelsene for denne gruppen kan bidra til lavere perinatal dødelighet både gjennom bedre overvåking og planlagt behandling, men også ved påvisning av alvorlige misdannelser der kvinnen søker om å avbryte svangerskapet.

\section{LITTERATUR}

1. Eskild A, Skau I, Haavaldsen C et al. Teknologi redder fosterliv. Tidsskr Nor Legeforen 2021; 141. doi: 10.4045/tidsskr.21.0256. [PubMed][CrossRef]

Publisert: 6. september 2021. Tidsskr Nor Legeforen. DOI:10.4045/tidsskr.21.058o

(C) Tidsskrift for Den norske legeforening 2023. Lastet ned fra tidsskriftet.no 26. april 2023. 